\title{
Leaf Traits as Functional Descriptors of the Intensity of Continuous Grazing in Native Grasslands in the South of Brazil
}

\author{
Pablo Cruz, ${ }^{1}$ Fernando Luis F. De Quadros, ${ }^{2}$ Jean Pierre Theau, ${ }^{3}$ Adriana Frizzo, ${ }^{4}$ Claire Jouany, ${ }^{1}$ \\ Michel Duru, ${ }^{1}$ and Paulo Cesar F. Carvalho ${ }^{5}$
}

Authors are ${ }^{1,5,6}$ Senior Research Scientists and ${ }^{3}$ Engineer, Institut National de la Recherche Agronomique-Unité Mixte de Recherche 1248 Agrosystèmes et developpement territorial, Castanet-Tolosan, France; ${ }^{2}$ Professor, Universidade Federal de Santa Maria, Santa Maria, Brazil; ${ }^{4}$ PhD Student and ${ }^{5}$ Professor, Universidade Federal do Rio Grande do Sul, Porto Alegre, Brazil.

\begin{abstract}
Plant functional types (PFT) have been used to describe the response of native vegetation to environmental factors (i.e., fertility) and to livestock disturbance, but rarely under conditions of continuous grazing. In this work we investigate whether the longterm response of grassland communities submitted to a gradient of continuous grazing pressure can be described with such an approach. After $15 \mathrm{yr}$ of differentiation of the grazing pressure applied to native grasslands we measured leaf dry-matter content (LDMC) and specific leaf area (SLA) of Poaceae populations of the communities. A grazing pressure gradient was created by levels of daily forage allowance: $4,8,12$, and $16 \mathrm{~kg}$ of dry matter per day per $100 \mathrm{~kg}$ of animal live weight, monitored monthly. PFTs were defined by numerical analysis, where an algorithm finds the optimal trait subset based on the agreement between matrices of species $\times$ traits, paddocks $\times$ grass biomass, and environmental variables (levels of forage allowance and soil characteristics). The results show that it is possible to describe a gradient of grazing pressure by means of LDMC and/or SLA measured only on the Poacea contributing at least $80 \%$ of the total Poaceae biomass. Four PFTs were differentiated by these leaf traits. PFTs having low LDMC and high SLA are characteristic of high intensity of use and are made up largely of stoloniferous $\mathrm{C}_{4}$ species typical of rapid resource capture strategies. Conversely, PFTs characterized by high LDMC and low SLA include species that are representative of low grazing pressure. Variations in the aggregate value of traits are due to changes in the species proportions and not to leaf-size adaptation as hypothesized. We conclude than in the absence of a gradient of fertility, plants with strategies of resource capture tend to be more represented under high grazing pressures. This situation results in a loss of functional diversity, but in particular a reduction in forage availability, which is incompatible with high animal production.
\end{abstract}

\section{Resumen}

La noción de grupos funcionales de plantas (GFP) ha sido utilizada para describir la respuesta de la vegetación nativa a los factores del medio (fertilidad) y al disturbio del pastoreo, pero pocos de dichos estudios han sido conducidos bajo condiciones de pastoreo continuo. En el presente trabajo se trata de verificar si dicho enfoque puede utilizarse para analizar la respuesta de la comunidad a un gradiente de presión de pastoreo continuo. Al término de 15 años de diferenciación continua de la presión de pastoreo ejercida sobre una pradera nativa, se midió el contenido de materia seca foliar (CMSF) y el área foliar específica (AFE) de las poblaciones de gramíneas presentes en la comunidad. El gradiente de pastoreo fue establecido según los niveles de oferta de forraje: 4, 8, 12, y $16 \mathrm{~kg}$ de materia seca por $100 \mathrm{~kg}$ de peso vivo por día, oferta ajustada mensualmente. Los GFP fueron definidos según un análisis numérico, donde un algoritmo identifica un subgrupo óptimo de características basado en la correspondencia entre matrices de [especies $\times$ atributos]; [praderas $\times$ biomasa de gramíneas] y variables como los niveles de oferta de forraje y características del suelo. Los resultados muestran que es posible describir el gradiente de presión de pastoreo en base a alCMSF y/o el AFE medidas sobre las gramíneas que contribuyen al menos el $80 \%$ de la biomasa total de gramíneas. Cuatro GFP fueron identificados gracias a dichos atributos. Los GFP que presentan bajo CMSF y alto AFE son característicos de altas intensidades de uso de la pradera donde dominan las especies estoloníferas las cuales típicamente disponen de estrategias de captura rápida de recursos. Por el contrario, los PFT caracterizados por altos CMSF y bajos AFE contienen especies representativas de situaciones con bajo nivel de presión de pastoreo. Las variaciones en los valores de los atributos ponderados son originadas por cambios en la proporción de especies y no por una adaptación del tamaño de las hojas como fue supuesto. Se concluye que en ausencia de un gradiente de fertilidad, las plantas con estrategia de captura rápida de recursos están mejor representadas en situaciones donde la presión de pastoreo es excesiva. Esta situación conduce a una pérdida de la diversidad funcional, pero sobre todo a una reducción de la disponibilidad forrajera a niveles incompatibles con una producción animal alta.

Key Words: grazing pressure, leaf dry matter content, plant functional types, Poacea, specific leaf area

Correspondence: Pablo Cruz, INRA-UMR 1248 AGIR, BP 52627, 31326 Castanet-Tolosan, France. Email: cruz@toulouse.inra.fr 


\section{INTRODUCTION}

Natural and seminatural grasslands occur extensively around the globe, but successful management for production and conservation of the biodiversity poses several dilemmas for farm managers (Watkinson and Ormerod 2001). Grazing is the most important factor affecting the herbaceous vegetation in most of the grassland areas of the world. Nevertheless, community responses to grazing are difficult to predict because of the large number of species in natural grasslands and the complexity of the mechanisms involved (Bullock and Marriot 2000). An example of the difficulty in predicting plant response to grazing is the controversial results reported when species are classified as "increasers" or "decreasers" (Landsberg 2001) in biomass proportion when they are grazed.

To establish a diagnosis of the state of the vegetation and to advise on its management, the question of botanical expertise remains the main constraint for development agents (Cruz et al. 2002). Therefore, an alternative to the analysis at the species level has been developed following the concept of plant functional types (PFTs; Gitay and Noble 1997). PFTs are groups of species that display similar biological traits at a given level of resource supply and/or disturbance intensity. These are, in relatively mesic areas, the most important factors driving changes in both botanical composition and agronomic properties of grasslands (Duru et al. 1998; Craine et al. 2001; Fynn et al. 2005). As a result, a diagnosis made from values of traits or dominant PFTs in grassland can be envisaged as an appropriate and objective option. Moreover, the advantage of using leaf functional traits as indicators of grazing intensity effects and nutrient availability, as compared with taxonomic or plant sociological methods, is their generality.

The analysis of the vegetation response to grazing through a functional approach has been successfully applied under temperate subhumid (Díaz et al. 2001) and humid conditions (Louault et al. 2005) as well as under dry environmental conditions (Landsberg et al. 1999). Nevertheless, under these last conditions Vesk et al. (2004) showed a lack of prediction of grazing response by simple plant traits and concluded that they probably are not appropriate to describe grasslands lacking a simple and continuous structure because of the high diversity of growth forms in rangelands. Moreover, a lack of grazing effect on the vegetation structure of semiarid rangelands was observed by Cipriotti and Aguiar (2005).

Under subtropical conditions, Sosinski and Pillar (2004) based PFTs on quantitative (e.g., leaf-blade width) and qualitative (e.g., texture of the leaf blade) traits, which, according to Garnier et al. (2007), are less related to plant function than leaf traits, like the specific leaf area (SLA) and the dry matter content of water-saturated leaves (leaf dry matter content [LDMC]). The choice of morphological (but not necessarily functional) traits used by Sosinski and Pillar (2004) could be the reason for the poor correlation between the PFT and the gradient of grazing pressure found by these authors. In spite of this poor correlation, the PFTs determined from qualitative traits explained the different grazing pressures $\left(r^{2}>0.5\right)$ better than the botanical composition of the grassland $\left(r^{2}<0.2\right)$. It would be logical to suppose that functional traits, or PFTs constructed from functional traits, should further improve the description of grazing pressure gradients compared with the qualitative traits used by these authors. The aim of this work is to describe by means of functional leaf traits the long-term responses of natural grasslands in the state of Rio Grande do Sul (Brazil) under a gradient of grazing pressures. A high grazing intensity prevents all animal selection and results in a closely cropped pasture. Such a canopy structure should result in less functional diversity, i.e., homogeneity of PFTs. Conversely, low grazing intensity produces a stand with patches of closely shaven and tall vegetation, or patches with plants at different phenological stages, which should lead to increased functional diversity.

Natural grasslands are facing conflicting pressures in Brazil. There is a demand to be productive, contributing to the country's development, and the concern for preservation, because lessons learned worldwide have shown huge social and economical implications in restoring degraded ecosystems. This dilemma reached a crucial point in southern Brazil, and the need to coordinate efforts between production and conservation-oriented policies in the Campos biome should be examined. The Brazilian part of the Campos (called Campos Sulinos) is located in the southwest of Rio Grande do Sul State and accounts for $90 \%$ of the grasslands in the state. It is dominated by grasses, mainly belonging to the Andropogon, Aristida, and Paspalum genera, but 400 grass species have been recorded (Boldrini 2007). It is the most important forage source for almost 13 million cattle and 5 million sheep. This natural grassland system is under threat, decreasing at a rate of 135,000 ha per year. The consequences of biome degradation include landscape fragmentation, loss of biodiversity, biological invasion, soil erosion, water pollution, land degradation, and heavy use of chemicals. Current estimates are that about 6 million ha of natural grassland remain (Hasenack et al. 2007). The harmful effect for Campos Sulinos is the loss of biodiversity and ecosystem services (Carvalho et al. 2006).

We hypothesize that a gradient of grazing pressure may be described by the proportion of species having different growth strategies that could be diagnosed by functional traits such as SLA and LDMC. Louault et al. (2005) showed that, in response to a decline in the disturbance regime, the vegetation displayed leaves with a higher LDMC and smaller SLA. Decreasing SLA and increasing LDMC are associated with conservative strategies (Garnier et al. 2007), which are typical of slowgrowing species. Conversely, species with a high SLA and low LDMC can be associated with resource-capture strategies of fast-growing species (Poorter and Bergkotte 1992). The fundamental difference between these two types of growth strategy is the density of the tissues. For an identical gain of biomass, the species with high tissue density have slow morphological development, which results in poor resource capture from the environment (especially light) because of a small organ volume. The LDMC is the leaf trait best correlated with plant tissue density (Ryser 1996; Weiher et al. 1999). Usually, SLA is a trait negatively correlated with LDMC. However, species that have evolved in a low-light microclimate exhibit simultaneously high SLA and high tissue density (or LDMC). This situation sometimes rends the SLA unsuitable as a response trait to discriminate PFTs.

Correspondence between the dominance of a particular PFT in grasslands and individual and general animal performance when grazing at different levels of grazing intensity shows the 
Table 1. Relative contribution of grasses expressed as the percentage of total biomass in the forage allowance treatments ( $r 1$ and $r 2$ are replications).

\begin{tabular}{|c|c|c|c|c|c|c|c|c|}
\hline \multirow[b]{3}{*}{ Species } & \multicolumn{8}{|c|}{ Forage allowance (kg dry matter per 100 kg live weight) } \\
\hline & \multicolumn{2}{|c|}{4} & \multicolumn{2}{|c|}{8} & \multicolumn{2}{|c|}{12} & \multicolumn{2}{|c|}{16} \\
\hline & r1 & r2 & $\mathrm{r} 1$ & r2 & $\mathrm{r} 1$ & r2 & r1 & r2 \\
\hline & \multicolumn{8}{|c|}{ - } \\
\hline Andropogon lateralis $\mathrm{G}$ & 4.38 & 3.75 & 15.42 & 10.69 & - & 6.15 & - & 24.4 \\
\hline Andropogon lateralis $\mathrm{T}$ & - & - & - & - & - & - & 5.17 & 4.00 \\
\hline Aristida spp. & - & - & - & - & - & - & 14.31 & 16.00 \\
\hline Axonopus affinis & - & 1.00 & 7.69 & 1.72 & 11.61 & 3.85 & 1.48 & 0.50 \\
\hline Coelorhachis selloana & - & - & - & - & - & - & - & 0.50 \\
\hline Panicum sabulorum & - & - & 0.38 & - & - & - & - & - \\
\hline Paspalum notatum & 55.00 & 64.50 & 29.27 & 55.17 & 36.23 & 50.88 & 10.28 & 23.90 \\
\hline Paspalum paucifolium & - & 7.5 & 3.46 & 5.69 & - & - & - & - \\
\hline Piptochaetium montevidense & 10.62 & 3.50 & 1.15 & - & 3.64 & 1.65 & 2.41 & 1.00 \\
\hline Sporobolus indicus & 3.75 & - & 4.35 & 1.72 & - & - & 1.38 & - \\
\hline
\end{tabular}

interest of a functional approach. It could clarify the consequences on the management of livestock systems in the natural grasslands of the south of Brazil.

\section{MATERIALS AND METHODS}

\section{Experimental Site and Measurements}

The experiment was carried out in the experimental area of the Universidade Federal do Rio Grande do Sul, Brazil, located in Eldorado do Sul, in Depressão Central region, where soils belong to the Rhodic Paleudult and Typic Plinthudult classes (US Department of Agriculture 1999). The climate at the experimental site is humid tropical with an annual rainfall of $1440 \mathrm{~mm}$, which is well distributed throughout the year. June is the wettest month $(168.2 \mathrm{~mm})$ and December the driest (97.7 mm; Bergamaschi and Guadagnin 1990). Its geographical coordinates are lat $30^{\circ} 05^{\prime} \mathrm{S}$, long $51^{\circ} 40^{\prime} \mathrm{W}$. Its altitude is $46 \mathrm{~m}$.

The treatments were four levels of daily forage allowance: 4 , 8,12 , and $16 \mathrm{~kg}$ of dry matter per $100 \mathrm{~kg}$ of animal live weight (LW) per day, maintained constant for $15 \mathrm{yr}$. Forage allowance is the relationship between the weight of forage dry matter per unit area and the number of animal units at a specific time, and is the inverse of grazing pressure (The Forage and Grazing Terminology Committee: http://forages.oregonstate.edu/topics/ description.cfm? TopID =604). So, low forage allowance signifies high grazing pressure.

There were no other interventions such as fertilization, irrigation, fire, and mowing. The experiment was arranged in blocks with two replicates (Nabinger 2002). The paddocks varied from 2.73 ha to 5.42 ha in area, with a mean of 4.5 ha, and present a slightly undulating relief. The soil drainage capacity was higher in the first block than in the second.

The intended levels of forage allowance were assured by monthly adjustment of the LW per treatment as a function of total forage availability estimated for the period by cutting three $0.25-\mathrm{m}^{2}$ quadrats in each plot. Five steers were maintained as testers plus the put-and-take animals needed to maintain the intended levels of forage allowance. The pastures were grazed by continuous stocking during the year.
During October and November 2002 (15 yr after the differentiation of grazing pressures), the LDMC and SLA were measured on grasses included in $80 \%$ of the grassland standing biomass. The measurements were made only on grasses as suggested by Ansquer et al. (2005) because dicotyledons have the same behavior as the associated grasses in a given plant community (Ansquer 2006). The use of grass populations is also supported by their high contribution to the grassland biomass and their agronomic value. The trait measurements were made following the protocol proposed by Garnier et al. (2001) and Cornelissen et al. (2003), i.e. on the youngest fully expanded leaves that had to be healthy and growing under full natural radiation (no shaded leaves). Leaves were previously water saturated by immersion in demineralized water for at least 8 h. LDMC and SLA were measured on 10 individuals per treatment per replicate. The area of leaves was determined with a leaf area meter (Li-Cor 2000). The minimal area measured per individual was $2 \mathrm{~cm}^{2}$. When the area of a leaf was less than this, leaves from new tillers were sampled and treated together as a single leaf. On three genera, Aristida, Piptochaetium, and Sporobolus, the SLA was estimated according to the model proposed by Garnier et al. (2001) because their needle-shaped laminae were not suitable for the Li-Cor area meter.

A list of the grasses measured in each treatment and per replication is given in Table 1. Andropogon lateralis was separated into $G$ and $T$ populations, which correspond to grazed and tufted individuals, respectively. $G$ and $T$ types were measured separately because they are morphologically very different (probably a plastic response to the grazing effect) and show contrasting values of leaf traits. The proportion of the species in the total biomass was estimated by the BOTANAL method (Tothill et al. 1992) with the use of a spreadsheet adaptation proposed by Martins and Quadros (2004). This method uses visual assessment of the contribution of the top five species to biomass. All species occurring in each $0.5 \times 0.5 \mathrm{~m}$ quadrat were recorded. In the visual assessment the different populations named $\mathrm{G}$ or $\mathrm{T}$ above were recorded separately.

The nitrogen nutrition index (NNI) was determined in order to assess the nitrogen availability to plant stands. It was calculated as 
Table 2. Averages and standard deviations for leaf traits for each treatment of forage on offer ( $\mathrm{kg}$ of dry matter [DM] per $100 \mathrm{~kg}$ of live weight [LW] per hectare per day).

\begin{tabular}{clcc}
\hline \multicolumn{1}{c}{ Treatment } & & Specific leaf area $\left(\mathrm{m}^{2} \cdot \mathrm{kg}^{-1}\right)$ & Leaf dry matter content $\left(\mathrm{mg} \cdot \mathrm{g}^{-1}\right)$ \\
\hline $4 \mathrm{~kg}$ of DM per $100 \mathrm{~kg}$ of LW & Weighted & 15.4 & 310.5 \\
& Not weighted & $14.1 \pm 4.9$ & $327.8 \pm 61.1$ \\
$8 \mathrm{~kg}$ of DM per $100 \mathrm{~kg}$ of LW & Weighted & 15.9 & 307.6 \\
& Not weighted & $17.0 \pm 6.5$ & $309.0 \pm 65.7$ \\
$12 \mathrm{~kg}$ of DM per $100 \mathrm{~kg}$ of LW & Weighted & 17.9 & 294.9 \\
& Not weighted & $14.7 \pm 6.3$ & $335.8 \pm 78.9$ \\
$16 \mathrm{~kg}$ of DM per $100 \mathrm{~kg}$ of LW & Weighted & 12.6 & 386.4 \\
& Not weighted & $13.2 \pm 6.1$ & $368.5 \pm 81.8$ \\
\hline
\end{tabular}

${ }^{1}$ Traits were weighted according to proportional grasses species abundance relative to total grass mass. Not weighted means a simple arithmetical average of trait values among grass species.

$$
\mathrm{NNI}=\left(\mathrm{N} \%_{\text {actual }} / \mathrm{N} \%_{\text {critical }}\right) \times 100,
$$

where $\mathrm{N} \%_{\text {actual }}$ is the $\mathrm{N} \%$ of the herbage sample and $\mathrm{N} \%_{\text {critical }}=3.6 \times(\mathrm{DM})^{-0.33}($ Cruz and Lemaire 1996) and $\mathrm{DM}$ is the production of the herbage sample in tons of dry matter per hectare.

This nitrogen nutrition index expresses the degree of satisfaction of nitrogen requirement for the grassland compared with an uptake permitting maximum growth, for which there is a critical nitrogen value for a given level of biomass (Lemaire and Gastal 1997). The critical value of $3.6 \%$ for a biomass of 1 tonne per hectare corresponds to that of $\mathrm{C}_{4}$ plants that have been analyzed. In fact, in view of the reproductive stage of $\mathrm{C}_{3}$ species, a stage during which the method cannot be applied, and the higher proportion of $\mathrm{C}_{4}$ species in the communities in November $(55 \%, 66 \%, 82 \%$, and $75 \%$ for $4,8,12$, and $16 \mathrm{~kg}$ DM per $100 \mathrm{~kg} \mathrm{LW}$, respectively), the critical value for $\mathrm{C}_{4}$ plants was used. Four samples of $0.25 \mathrm{~m}^{2}$ per plot (i.e., for each of the 4 treatments $\times 2$ replicates) were taken. Each sample was then sorted to separate the $\mathrm{C}_{3}$ and $\mathrm{C}_{4}$ species, and dried at $80^{\circ} \mathrm{C}$ for $48 \mathrm{~h}$ to determine the total dry matter. Total $\% \mathrm{~N}$ was measured with the use of a CHN 2000 analyzer (Leco, St. Joseph, MI) after grinding the $\mathrm{C}_{4}$ fraction $(0.5-\mathrm{mm}$ mesh). At the time of biomass sampling, soil samples $(0-5-\mathrm{cm}$ layer $)$ were collected with a hand auger, discarding any upper root material present. In each plot 10-20 cores, evenly distributed over the whole plot area, were collected and bulked to make a composite sample representative of the plot. Soils were crumbled by hand and dried for $1 \mathrm{wk}$ at room temperature, then sieved (2-mm mesh) before analysis for total C, N, and organic matter $(\mathrm{OM})$ concentrations, as well as the $\mathrm{pH}_{\text {water }}$. All soil samples were analyzed according to the Laboratoire d'Analyses des Sols of the National Institute for Agronomic Research (INRA, 62000 Arras, France) with the use of standard procedures (Afnor 1994).

\section{Data Analysis}

We used an approach proposed by Pillar and Sosinski (2003) to test the congruence of PFTs and specified environmental variables. Soil variables and forage allowance levels were considered as environmental variable matrices. Grasses and their respective average values of LDMC and SLA constituted another species $\times$ characters matrix. A third matrix consisted of each species with its average biomass contribution in each paddock, calculated by the spreadsheet proposed by Martins and Quadros (2004). An algorithm uses these three matrices to define functional types whose performance in the community presented a maximum association with the specified environmental variables. After the definition of the PFTs, we used a principal coordinates ordering to evaluate groups and environmental variable relations and randomization tests to establish the significance levels of differences among those PFTs. All these analyses were performed using Euclidian distance as a dissimilarity measure between sampling units with SYNCSA and MULTIV software (Pillar 2004). Functional groups of species were defined by numerical analysis, where an algorithm finds the optimal trait subset in a PFT based on the agreement between matrices of species $\times$ traits, paddocks $\times$ grass biomass, and environmental variables (levels of DM available; soil characteristics).

Functional diversity was expressed by the Rao coefficient as a functional diversity (FD) index (Lepš et al. 2006):

$$
\mathrm{FD}=\sum_{i=1}^{s} \sum_{j=1}^{s} D_{i j} P_{i} P_{j},
$$

where the proportion on the community of $i$ th species is $P_{i}$ and dissimilarity of species $i$ and $j$ is $D_{i j}$. $s$ is the number of species in the community (in our case the number of perennial grasses).

\section{RESULTS}

\section{Trait Values}

The values of leaf traits weighted or not by the relative abundance of grasses in the grass forage mass are shown in Table 2. The weighted values of LDMC are higher at the low grazing pressure, whereas the other three grazing pressures have similar values. LDMC and SLA data confirm the negative correlation that exists between these two traits, as shown by Garnier et al. (2001).

\section{Nitrogen Availability}

There was no significant effect $(P \geq 0.46)$ of grazing pressure on the soil $\mathrm{N}$ availability measured through the NNI of stands (Table 3). This lack of difference was in agreement with the soil data. In view of this result one can conclude that the differences in the values of the leaf traits are not due to nitrogen availability, but are, rather, a reflection of the difference 
Table 3. Nitrogen nutrition index (NNI), soil carbon (C), soil organic matter (OM), soil nitrogen (N), and soil pH through the gradient of forage allowance. Data are the averages of two paddocks per treatment (replicates) after $15 \mathrm{yr}$ of the treatments. There is no significant difference between treatments for any of variables (standard error in parentheses).

\begin{tabular}{|c|c|c|c|c|c|c|}
\hline Treatments & NNI & $C\left(g \cdot \mathrm{kg}^{-1}\right)$ & $\mathrm{OM}\left(\mathrm{g} \cdot \mathrm{kg}^{-1}\right)$ & $\mathrm{N}\left(\mathrm{g} \cdot \mathrm{kg}^{-1}\right)$ & $\mathrm{C} / \mathrm{N}$ & $\mathrm{pH}$ \\
\hline 4 kg dry matter (DM) per $100 \mathrm{~kg}$ live weight (LW) & $53(5.5)$ & $13.6(1.8)$ & $23.4(3.0)$ & $1.02(0.1)$ & 13.3 & $5.4(0.1)$ \\
\hline 8 kg DM per 100 kg LW & $62(9.8)$ & $13.7(4.1)$ & $23.6(6.3)$ & $1.06(0.3)$ & 12.9 & $5.4(0.1)$ \\
\hline $12 \mathrm{~kg}$ DM per $100 \mathrm{~kg} \mathrm{LW}$ & $57(5.4)$ & $16.3(2.1)$ & $28.0(3.7)$ & $1.21(0.2)$ & 13.5 & $5.3(0.2)$ \\
\hline 16 kg DM per $100 \mathrm{~kg} \mathrm{LW}$ & $61(9.6)$ & $14.3(3.8)$ & $24.5(6.6)$ & $1.10(0.3)$ & 13.0 & $5.4(0.3)$ \\
\hline Probability & $n s^{1}$ & ns & ns & ns & & ns \\
\hline
\end{tabular}

${ }^{1}$ ns indicates not significant.

between the grass species present in the treatments (nonweighted or nonaggregated traits) or to a difference in their proportion (weighted or aggregated traits).

\section{Floristic Composition}

Besides the contribution of grass species (Table 1) the grassland composition of this trial can be illustrated by the botanical family of the species that accounted for most (above $3 \%$ ) of the biomass in the evaluations made during the growing season (Table 4). On this basis, grasses accounted for $68 \%$ of total aboveground biomass (ranging from $48 \%$ to $80 \%$, according to plots).

Table 4 shows that whatever the treatment considered, species of the Poaceae family represent about half of total number of species. This total is lower with the highest grazing pressure (4 kg DM per $100 \mathrm{~kg} \mathrm{LW)} \mathrm{showing} \mathrm{a} \mathrm{loss} \mathrm{of} \mathrm{grass}$ species diversity in this treatment.

Of all the Poaceae species, seven made the major contribution to the DM of grasses. Two species occurred in all plots: Paspalum notatum, which averaged 58\% (ranging from 21\% to $80 \%$, according to plots) and Andropogon lateralis, with an average of $19 \%$ (from $5 \%$ to $40 \%$ ). Two other grasses were represented in seven of the eight plots, Axonopus affinis averaging $6 \%$ (ranging from $1 \%$ to $18 \%$ ) and Piptochaetium montevidense, which represented $5 \%$ (from $1 \%$ to $13 \%$ ) of the grass biomass in the plots where they occurred.

There was one grass, Paspalum paucifolium, that occurred mostly in the heavily grazed paddocks (4 and $8 \mathrm{~kg}$ DM per $100 \mathrm{~kg} \mathrm{LW})$, which accounted for $7 \%$ of the grass biomass (from $6 \%$ to $9 \%$ ). One genus, Aristida, was present only in the

Table 4. Grassland composition evaluated at the experimental site, in spring 2002, according to the assigned treatments (averages of two paddocks per treatment). The total number of species in all the treatments is in parentheses.

\begin{tabular}{ccccc}
\hline & \multicolumn{4}{c}{$\begin{array}{c}\text { Number of species in the botanical } \\
\text { families represented }\end{array}$} \\
\cline { 2 - 5 } Treatments & $\begin{array}{c}\text { Poaceae } \\
(20)\end{array}$ & $\begin{array}{c}\text { Fabaceae } \\
(3)\end{array}$ & $\begin{array}{c}\text { Others } \\
(15)^{1}\end{array}$ & $\begin{array}{c}\text { Totals } \\
(38)\end{array}$ \\
\hline 4 kg dry matter (DM) per & & & & \\
100 kg live weight (LW) & 6 & 1 & 5 & 12 \\
8 kg DM per 100 kg LW & 13 & 1 & 10 & 24 \\
12 kg DM per 100 kg LW & 10 & 2 & 10 & 22 \\
16 kg DM per 100 kg LW & 14 & 0 & 7 & 21 \\
\hline
\end{tabular}

${ }^{1}$ Other families are Acantaceae, Asteraceae, Campanulaceae, Cyperaceae, Iridaceae, Juncaceae, Rubiaceae, and Umbelliferae. lightly grazed plots (16 kg DM per $100 \mathrm{~kg} \mathrm{LW),} \mathrm{accounting} \mathrm{for}$ $26 \%$ of total grass availability (from $23 \%$ to $30 \%$ ). The last species considered was Sporobolus indicus, which was present in six paddocks at an average of $3 \%$ (from $1 \%$ to $7 \%$ ). Figure 1 presents a synthesis in two-dimensional space of the grass composition in each treatment replicate. It shows that there was a directional trend linked to the horizontal axis from the lower to the higher forage allowance with the species already mentioned. The tufted grasses are correlated to the higher allowance treatment and some prostrate species of the genus Paspalum are correlated with the lower forage allowance. In the intermediate allowance treatments, within-replicate differences made it difficult to establish which species were driving the process.

The position of the first group of replicates (1), mainly in the upper part of the diagram, and of the second group (2) below it, can be attributed to soil variables, bearing in mind that replicates are on different soil classes. Besides that, treatments were similar $(P \geq 0.33)$ with regard to soil $\% \mathrm{C}, \mathrm{OM}$, and $\mathrm{N}$; $\mathrm{C} / \mathrm{N}$ and $\mathrm{pH}$ (Table 3 ).

Leaf Size Across a Grazing Pressure Gradient. A reduction in leaf size may be a consequence of the increase in the frequency

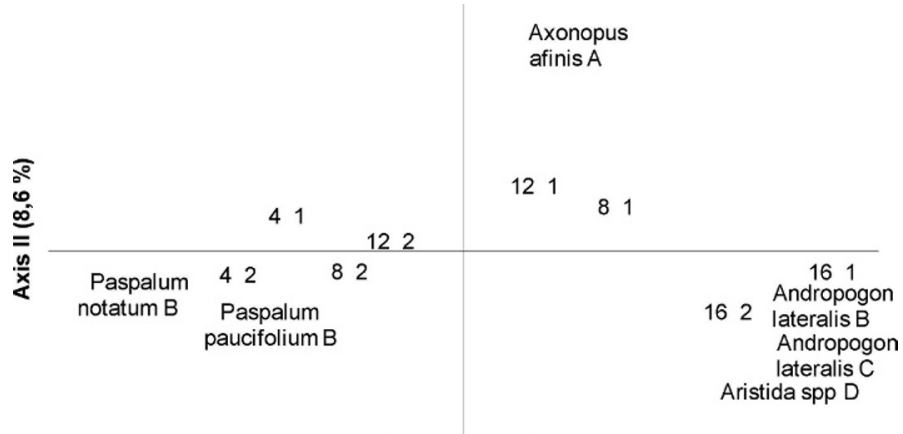

Axis I $(84,4 \%)$

Figure 1. Ordination diagram (principal coordinate analysis, using Euclidian distance) of grass dry matter (DM) availability of paddocks under different levels of forage allowance, which are as follows: 4, 8, 12, 16 (kg DM per $100 \mathrm{~kg}$ of live weight) are the increasing amounts of forage allowance, with its respective replicates (1 and 2). The indicated species are those with a correlation higher than 0.81 with one of the ordination axes, being Andropogon lateralis $\mathrm{B}=$ grazed plants of Andropogon lateralis; Andropogon lateralis $\mathrm{C}=$ ungrazed or slightly grazed plants (tufted) of Andropogon lateralis; Aristida spp. D = species of the Aristida genus. The horizontal axis $(X)$ accounts for $84.4 \%$ and the vertical axis $(Y)$ accounts for $8.6 \%$ of total variation. 
Table 5. Morphological characteristics (leaf area) and functional leaf traits (leaf dry matter content $=$ LDMC and specific leaf area $=S L A$ ) of Paspalum notatum across grazing pressure treatments. The standard error of the measurements is in parentheses.

\begin{tabular}{lcccc}
\hline & \multicolumn{4}{c}{ Grazing pressure levels (kg of dry matter per $100 \mathrm{~kg}$ of } \\
& 4 & 8 & 12 & 16 \\
\cline { 2 - 5 } & 4 & \multicolumn{4}{c}{ live weight per day) } \\
\hline Leaf area $\left(\mathrm{cm}^{2}\right)$ & $1.11(0.26)$ & $1.87(0.55)$ & $2.62(0.66)$ & $3.35(1.34)$ \\
LDMC $\left(\mathrm{mg} \cdot \mathrm{g}^{-1}\right)$ & $297(6.0)$ & $297(1.4)$ & $295(1.2)$ & $305(33.1)$ \\
SLA $\left(\mathrm{m}^{2} \cdot \mathrm{kg}^{-1}\right)$ & $16.6(0.6)$ & $15.5(2.4)$ & $17.8(0.1)$ & $16.5(1.3)$ \\
\hline
\end{tabular}

of defoliation. Such a response could result in a reduction in the LDMC and an increase in SLA due to a reduction in the proportion of supporting tissues in the grass leaf. This response is not observed in the case of the most abundant species, common to all treatments, Paspalum notatum (Table 5). This result indicates that the hypothesis of variation in leaf traits concomitant with variations in leaf size is untenable due to the low plasticity of leaf traits, and that variations in the values of the traits between treatments is more likely due to changes in the floristic composition.

Leaf Traits and PFTs. The measured traits for the grasses that account for most of the biomass are presented in Table 6. As Coelorachis selloana had a contribution of less than $1 \%$ and was restricted to only one paddock, it was not included.

The variation in values of LDMC and especially of SLA of Andropogon lateralis growth forms should be noted, illustrating the plasticity of the species. By combining trait values from Table 6 with species biomass contribution data (from Table 1), it was possible to separate the grasses into four functional groups. The types were defined after a cluster analysis, where different partition levels (number of groups) were evaluated. With the use of a combination of LDMC and SLA, the four groups above reached $84 \%$ of the maximal congruence. Considering those criteria applied to the dominant grass communities, the groups formed by the combinations of

Table 6. Leaf dry matter content (LDMC; $m g \cdot g^{-1}$ ) and specific leaf area $\left(\mathrm{SLA} ; \mathrm{m}^{2} \cdot \mathrm{kg}^{-1}\right)$ measured in grasses that accounted for most of the aerial biomass in spring 2002. For Andropogon lateralis $\mathrm{G}$ and $\mathrm{T}$ represents "grazed" and "tufted," considered as two growth forms of this species.

\begin{tabular}{|c|c|c|c|c|}
\hline \multirow[b]{2}{*}{ Species } & \multicolumn{2}{|c|}{ LDMC $\left(\mathrm{mg} \cdot \mathrm{g}^{-1}\right)$} & \multicolumn{2}{|c|}{$\operatorname{SLA}\left(\mathrm{m}^{2} \cdot \mathrm{kg}^{-1}\right)$} \\
\hline & Average & Range & Average & Range \\
\hline Andropogon lateralis $\mathrm{G}$ & 330 & $297-378$ & 15.2 & $14.5-16.5$ \\
\hline Andropogon lateralis $\mathrm{T}$ & 364 & $359-370$ & 9.2 & $8.5-9.8$ \\
\hline Aristida spp. ${ }^{1}$ & 505 & $496-520$ & 6.0 & $5.7-6.2$ \\
\hline Axonopus affinis & 234 & $220-258$ & 24.2 & $22.4-25.6$ \\
\hline Coelorachis selloana & 309 & $291-327$ & 21 & 18-23 \\
\hline Panicum sabulorum & 233 & $213-253$ & 26 & $22-29$ \\
\hline Paspalum notatum & 298 & $282-329$ & 16.6 & $13.8-17.9$ \\
\hline Paspalum paucifolium & 301 & $270-310$ & 16.8 & 13.9-20.9 \\
\hline \multicolumn{5}{|l|}{ Piptochaetium } \\
\hline montevidense $e^{1}$ & 405 & $390-426$ & 8.6 & $7.9-9.9$ \\
\hline Sporobolus indicus ${ }^{1}$ & 391 & $374-399$ & 9.1 & $8.8-9.7$ \\
\hline
\end{tabular}

\footnotetext{
${ }^{1}$ Species that had their values of SLA estimated by Garnier's model (Garnier et al. 2001).
}

Table 7. Groups of plant functional types (PFTs) based on leaf drymatter content (LDMC; $\left.\mathrm{mg} \cdot \mathrm{g}^{-1}\right)$ and specific leaf area $\left(\mathrm{SLA} ; \mathrm{m}^{2} \cdot \mathrm{kg}^{-1}\right)$. $\mathrm{G}$ and $\mathrm{T}$ identify grazed or tufted types of Andropogon lateralis.

\begin{tabular}{cccc}
\hline Groups & $\begin{array}{c}\mathrm{LDMC} \\
\left(\mathrm{mg} \cdot \mathrm{g}^{-1}\right)\end{array}$ & $\begin{array}{c}\mathrm{SLA} \\
\left(\mathrm{m}^{2} \cdot \mathrm{kg}^{-1}\right)\end{array}$ & Species \\
\hline A & 230 & 24 & $\begin{array}{c}\text { Axonopus affinis, Panicum sabulorum } \\
\text { Andropogon lateralis G, Coelorachis selloana, } \\
\text { B }\end{array}$ \\
310 & 16 & 8 & $\begin{array}{c}\text { Andropogon lateralis T, Piptochaetium } \\
\text { montevidense, Sporobolus indicus }\end{array}$ \\
C & 380 & 6 & $\begin{array}{c}\text { Aristida spp. (Aristida laevis, Aristida } \\
\text { phylifolia, Aristida venustula) }\end{array}$ \\
D & 500 & &
\end{tabular}

LDMC and SLA are described in Table 7. Groups A and B, formed by grasses with low to intermediate values of LDMC and relatively high SLA, could be assigned to a "resource capture strategy" group. Groups C and D are formed by species having higher tissue densities characterized by the most correlated foliar trait to it, the LDMC (Ryser 1996). These species could be assigned to the "conservative resource strategy."

\section{Functional Diversity}

Table 8 shows the values of functional diversity for both LDMC and SLA. We see a big loss of functional diversity in the treatment with the highest grazing pressure. Conversely, low grazing pressure results in the highest FD, the two other treatments being intermediate.

The functional diversity of different grazing pressures is also shown by the frequency of distribution of PFTs (Fig. 2). It shows that the only situation where the four PFTs are represented was those of the lowest grazing pressure $(16 \mathrm{~kg}$ of DM per $100 \mathrm{~kg}$ of LW) in both replicates. This is in accord with the higher functional diversity displayed by the Rao coefficient (Table 8). Conversely, replicate 1 of the highest grazing pressure ( $4 \mathrm{~kg}$ of DM per $100 \mathrm{~kg}$ of LW) contains only two groups, B and C.

\section{DISCUSSION}

\section{Grass Leaf Traits and Morphological Adaptation of Leaves}

Most studies analyzing the effect of grazing intensity do not check for possible interactions with the nutrient status of the stands, leaving doubt as to the reason for the differences in results. In our trial, the NNI of plant stands and data from soil variables $(\% \mathrm{~N}, \% \mathrm{OM})$ show a great independence between the availability of nitrogen (which was the same for all treatments) and the gradient of grazing pressure even after $15 \mathrm{yr}$ of maintaining the same treatments. This means that different grazing pressures have not yet had a chance to generate differences in soil nutrient content. The tendency to have a lower value (although not significantly) of NNI and soil N observed in the highest grazing pressure treatment $(4 \mathrm{~kg}$ of DM per $100 \mathrm{~kg}$ of LW; Table 3) could be related to a lower oxygenation of the soil, which is a consequence of the higher 
Table 8. Functional diversity (FD, Rao coefficient) at the four levels of herbage allowance $(4,8,12$, and $16 \mathrm{~kg}$ of dry matter per $100 \mathrm{~kg}$ of live weight per hectare per day) calculated for two leaf traits: LDMC (leaf dry matter content) and SLA (specific leaf area). Replicates of the treatments are indicated by $\mathrm{r} 1$ and $\mathrm{r} 2$.

\begin{tabular}{|c|c|c|c|c|c|c|c|c|}
\hline \multirow{2}{*}{$\begin{array}{l}\text { Treatments: } \\
\text { Replications: }\end{array}$} & \multicolumn{2}{|c|}{4} & \multicolumn{2}{|c|}{8} & \multicolumn{2}{|c|}{12} & \multicolumn{2}{|c|}{16} \\
\hline & r1 & r2 & $\mathrm{r} 1$ & r2 & $\mathrm{r} 1$ & r2 & $\mathrm{r} 1$ & r2 \\
\hline FD-LDMC & 0.01 & 0.009 & 0.061 & 0.022 & 0.048 & 0.022 & 0.189 & 0.136 \\
\hline FD-SLA & 0.006 & 0.005 & 0.038 & 0.014 & 0.026 & 0.014 & 0.099 & 0.074 \\
\hline
\end{tabular}

stocking rate (trampling) as suggested by Mello et al. (2004) and Matsuoka et al. (2004).

In view of the lack of evidence for a fertility gradient between treatments, the data could be interpreted solely from a gradient of utilization. This gradient is described by a high LDMC and a low SLA when the grazing pressure is lower. Our results differ from those reported by Ansquer et al. (2004), where the intensity of defoliation did not alter the value of these leaf traits likely because of a lack of adaptation of leaf size to the different defoliation regimes. In fact, even in the most frequent cutting regime the cuts were sufficiently far apart in time to allow the leaves to reach their normal size. Following the same hypothesis whereby the reduction in leaf size would result in a reduction in LDMC and an increase in SLA, in our experiment, continuous grazing could have caused a reduction in their size as the grazing pressure became stronger. We have shown that for a species common to the four treatments (Paspalum notatum) the final size of leaves (in centimeters squared) of the grazed layer becomes greater as the grazing pressure falls (Table 5) but that it has no consequences on the leaf traits. The decrease in size of photosynthetic structures and the concentration of the leaf biomass at the soil level in conditions of high intensity of disturbance due to the action of herbivores have been previously described by Díaz et al. (1992), Fahnestock and Detling (2000), and Díaz et al. (2001). This morphological response to intensity of utilization is confirmed by the development under low grazing pressure of individuals of Andropogon lateralis (the other species common to all the treatments) with a tufted form. Thus the changes in values of these traits on the scale of the grass community following the gradient of grazing pressure are due not to changes in the size of

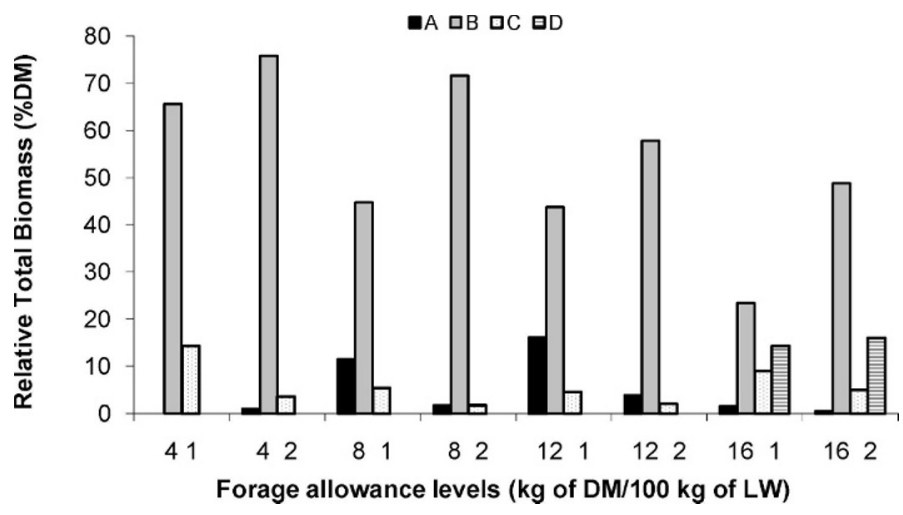

Figure 2. Histogram of frequency distribution of plant functional types (PFTs) in each replicate ( $r 1$ and $r 2$ ) of forage allowance treatments, where 4, 8, 12, 16 are the increasing amounts of daily forage allowance ( $\mathrm{kg}$ dry matter per $100 \mathrm{~kg}$ live weight). The PFT groups are according to Table 7. leaves of the species of the grazed layer, but rather to the increasing contribution of species included in the types $\mathrm{C}$ ( $A$. lateralis form $\mathrm{T}$ ) and $\mathrm{D}$ (Aristida sp.), and a decline in species of type B (P. paucifolium and notably P. notatum) as the grazing pressure falls.

On the other hand, the decrease in size of aerial organs could affect the herbage intake by ruminants, which may be lower at high grazing pressure. A lower herbage intake could explain the negative correlation between the individual LW gain and the grazing pressure reported by Nabinger et al. (2000).

\section{Strategies of Species and Utilization Gradients}

In Figure 1 we can observe a horizontal axis related to higher LDMC and lower SLA, principally linked to the contribution of tufted grasses such as A. lateralis and Aristida species and the treatment with the highest forage allowance $(16 \mathrm{~kg}$ of DM per $100 \mathrm{~kg} \mathrm{LW})$, on the right of the diagram. This side of the figure can be considered as the conservative strategy spectrum $(\mathrm{C}$ and $\mathrm{D}$ groups) of the pasture plant community. On the opposite side are the treatments with a lower forage allowance and the functional group B (i.e., capture strategy species like $P$. notatum and $P$. pancifolium). Besides the lower contribution of axis 2 (about $9 \%$ of total variation) it is clear that the main difference between treatments with an intermediate allowance ( 8 and $12 \mathrm{~kg}$ DM per $100 \mathrm{~kg} \mathrm{LW}$ ) and the one with the lowest (4 kg DM per $100 \mathrm{~kg}$ LW) could be attributable to the contribution of PFT A to its biomass. This PFT is a capture strategy group characterized by a higher SLA, as can be seen in Table 7.

Most of the species that form groups $\mathrm{A}$ and $\mathrm{B}$ are of the stoloniferous type. On the other hand, types $\mathrm{C}$ and $\mathrm{D}$ are composed of tillering types, a structure that in the gradient analysed corresponds to a strategy of resource conservation. This differentiation of species strategies, or values of based on their foliar traits that identify them (Poorter et al. 1990), does not necessarily indicate their ability to grow in more or less fertile environments as earlier work has suggested (Ackerly and Bazzaz 1995; Ryser and Lambers 1995; Knops and Reinhart 2000; Cruz et al. 2002; Al Haj Khaled et al. 2005). In view of the absence of any difference in the availability of nitrogen for the plants between the different grazing pressure situations, the capture strategy in the gradient analyzed here would correspond rather to an adaptation to maximizing the interception of the light resource permitted in stoloniferous types of plant. In fact, this morphological type allows light interception to be optimized at low leaf area index (LAI) values (Sinoquet et al. 1990).

\section{Functional Indicators of a Utilization Gradient}

Our results show that it is possible to describe a gradient of utilization intensity of continuously grazed pastures by means of the foliar traits of the dominant grasses in the community. A 
high LDMC and/or a low SLA are characteristic of conditions of high grazing pressure, because of a higher contribution of stoloniferous species with a capture strategy. On the other hand, low grazing pressure favors the growth of tillering species (Sporobolus indicus, Aristida spp., tufted forms of A. lateralis), plant types that maintain their considerable height by a substantial accumulation of senescent material (Louault 1999). This grass morphology allows different grazing in seasons of low rainfall. In this situation, the interplot functional diversity is increased. FD is useful to analyze the effects of diversity on ecosystem functioning. FD, measured as the divergence of leaf trait values between species, can be a better descriptor of ecosystem functioning than the number of functional groups (Lepš et al. 2006). Nevertheless in our experiment both FD of trait values and number of functional groups follows the same trend, because these groups have been constructed from the same leaf trait values.

Such an increase in the diversity of PFTs is not necessarily associated with better overall livestock performance. In fact, it has been shown (Nabinger et al. 2000) that live weight gain per hectare is greater in the intermediate treatments $(110,145,125$, and $80 \mathrm{~kg} \cdot \mathrm{ha}^{-1}$ in $16,12,8$, and $4 \mathrm{~kg}$ of DM per $100 \mathrm{~kg} \mathrm{LW}$, respectively). This better animal growth was probably made possible by the higher proportion of type $\mathrm{A}$ species in the 12 and $8 \mathrm{~kg}$ of DM per $100 \mathrm{~kg} \mathrm{LW}$ treatments (notably in replicate 1). The poorer performance of the $4 \mathrm{~kg}$ of DM per $100 \mathrm{~kg} \mathrm{LW}$ treatment can be attributed to the extremely low forage availability, which agrees with the low individual live weight gain also reported by Nabinger et al. (2000; 0.5, 0.5, 0.4, and $0.2 \mathrm{~kg}$ per animal per day in $16,12,8$, and $4 \mathrm{~kg}$ of DM per $100 \mathrm{~kg} \mathrm{LW}$, respectively).

In spite of a greater within-paddock diversity of PFTs, the poorer animal performance per hectare of the $16 \mathrm{~kg}$ of DM per $100 \mathrm{~kg} \mathrm{LW}$ treatment may be due to the presence of a large proportion of PFT D, a group made up of species hardly eaten by livestock. The high LDMC of this PFT is an indicator of low nutritive value (Al Haj Khaled et al. 2006). Conversely, the low stocking rate enables strong selection of the pasture, which explains the good individual performance of the animals.

We may conclude that in conditions of continuous grazing, where the functional diversity between paddocks plays no role, high within-paddock diversity may be detrimental in terms of total animal production if it implies the presence of species that are undesirable for animal consumption. Species of low nutritive value do not seem to play an important role in seasons or periods when forage availability is low.

\section{IMPLICATIONS}

We have shown that the grassland species with a resource capture strategy (PFT A and B) characterized by low values of LDMC and high values of SLA are most abundant under conditions of intensive grazing. They are mainly stoloniferous grasses, which optimize light interception. Their abundance in the grassland biomass makes it possible to discern a gradient of grazing pressure. Nevertheless these species can be very common under conditions of overgrazing where the quantity of available herbage limits good animal husbandry practices. On the other hand, under conditions of undergrazing it is the strong presence of PFT D, which by their poor nutritive value limits animal production. Good grassland management under continuous grazing should be guided so as to favor the presence of grasses of PFT A and B without overly reducing the quantity of available herbage. The appearance of the $\mathrm{T}$ form of $A$. lateralis and of the genus Aristida can be used as an indicator beyond which grazing pressure becomes too low.

\section{ACKNOWLEDGMENTS}

The authors thank Professors Gerzy Maraschin and Carlos Nabinger for making the experiment available to us; Professor Ilsi Boldrino for her botanical expertise; José Pedro Trindade (Empresa Brasileira de Pesquisa Agropecuária) for help with statistical analysis, and numerous students from Universidade Federal Do Rio Grande do Sul who over the course of the $15 \mathrm{yr}$ of the experiment helped with its maintenance. This study was made possible by the bilateral collaboration program CAPES-COFECUB 484/05/07 and l'INRA (Intitut National de la Recherche Agonomique).

\section{LITERATURE CITED}

Ackerly, D. D., AND F. A. Bazzaz. 1995. Leaf dynamics, self-shading and carbon gain in seedling of tropical pioneer tree. Oecologia 101:289-298.

Afnor. 1994. Qualité des sols. Volume 1. Recueil de normes. Paris, France: Afnor. Al Haj Khaled, R., M. Duru, V. Decruyenaere, C. Jouany, and P. Cruz. 2006. Using leaf traits to rank native grasses according to their nutritive value. Rangeland Ecologia and Management 59:648-654.

Al Haj Khaled, R., M. Duru, J. P. Theau, S. Plantureux, and P. Cruz. 2005. Variation in leaf traits through seasons and $\mathrm{N}$-availability levels and its consequences for ranking grassland species. Journal of Vegetation Science 16:391-398.

Ansquer, P. 2006. Agro ecological characterisation of native vegetation of grasslands in response to the management practises. Contribution to building diagnosis tools [thesis]. Toulouse, France: INP. 268 p. (In French).

Ansquer, P., P. Cruz, J. P. Theau, E. Lecloux, and M. Duru. 2005. How to simplify tools for natural grassland characterisation based on biological measures without losing too much information? Proceedings of the XX International Grasslands Congress. Glasgow: Wageningen Academic Publishers. 197 p.

Ansquer, P., J. P. Theau, P. Cruz, J. Viegas, R. Al Haj Khaled, and M. Duru. 2004. Characterisation of the functional diversity in native grasslands. A step in the process of building tools to manage vegetations with high number of species. Fourrages 179:353-368. (In French).

Bergamaschi, H., And M. R. Guadagnin. 1990. Agroclima da Estacion Agronomica da UFGRS. Porto Alegre: Universidade Federal Do Rio Grande do Sul. 97 p.

BoLdRIII, I. I. Formações campestres no sul do Brasil: Origem e modificadores. In: M. Dall'Agnol, C. Nabinger, D. M. Sant'Anna, and R. J. Santos [eds.]. Sustentabilidade produtiva no Bioma Pampa. II Simpósio de Forrageiras e Produção Animal. Porto Alegre, Brazil: Departamento de Forrageiras e Agrometeorologia - Universidade Federal Do Rio Grande do Sul. p. 7-13.

Bullock, J. M., And C. A. Marriot. 2000. Plant responses to grazing and opportunities for manipulation. In: A. J. Rook and P. D. Penning [EDS.]. Grazing management. Reading, United Kingdom: British Grassland Society. p. 17-26.

Carvalho, P. C. F., V. Fischer, D. T. dos Santos, A. M. L. Ribeiro, F. L. F. Quadros, Z. M. S. Castilhos, C. H. E. Poli, A. L. G. Monteiro, C. Nabinger, T. C. M. Genro, and A. V. A. Jacques. 2006. Produção animal no Bioma Campos Sulinos. Revista Brasileira de Zootecnia 35:156-202.

Cipriotti, P. A., And M. R. Agular. 2005. Effects of grazing on patch structure in a semiarid two-phase vegetation mosaic. Journal of Vegetation Science 16:57-66.

Cornelissen, J. H. C., S. Lavorel, E. Garnier, S. Diaz, N. Buchmann, D. E. Gurvich, P. B. Reich, H. ter Steege, H. D. Morgan, M. G. A. van der Heidden, J. G. Pausas, And H. Poorter. 2003. A handbook of protocols for standardised and easy measurement of plant functional traits worldwide. Australian Journal of Botany 51:335-380. 
Craine, J. M., J. Froehle, D. G. Tilman, D. A. Wedin, and F. S. Chapin. 2001. The relationships among root and leaf traits of 76 grassland species and relative abundance along fertility and disturbance gradients. Oikos 93:274-285.

Cruz, P., And M. Lemaire. 1996. Diagnosis of the nitrogen status of grass stands. Principles and uses of the dilution curves method. Tropical Grasslands 30:166.

Cruz, P., P. Sire, R. Al Haj Khaled, J. P. Theau, 0. Therond, and M. Duru. 2002. Plant functional traits related to growth strategies and habitat preference of native grass populations. Proceedings of the XIX European Grassland Federation; 27-30 May 2002; La Rochelle, France. p. 776-777.

Díaz, S., A. Acosta, and M. Cabido. 1992. Morphological analysis of herbaceous communities under different grazing regimes. Journal of Vegetation Science 3:689-696.

Díaz, S., I. Noy-Meir, and M. Cabido. 2001. Can grazing response of herbaceous plants be predicted from simple vegetative traits? Journal of Applied Ecology 38:497-508.

Duru, M., G. Balent, A. Gibon, D. Magda, J. P. Theau, P. Cruz, and C. Jouany. 1998. Functioning and dynamics of grasslands. The example of Central Pyrenees. Fourrages 153:97-113. (In French).

Fahnestock, J. T., and J. K. Detling. 2000. Morphological and physiological responses of perennials grasses to long-term grazing in the Pryor Mountains, Montana. American Midland Naturalist 143:312-320.

Fynn, R. W. S., C. D. Morris, and K. P. Kirkman. 2005. Plant strategies and trait trade-offs influenced in competitive ability along gradients of soil fertility and disturbance. Journal of Ecology 93:384-394.

Garnier, E., S. Lavorel, P. Ansquer, H. Castro, P. Cruz, J. Dolezal, 0. Eriksson, C. Fortunel, H. Freitas, C. Golodets, K. Grigulis, C. Jouany, H. Kazakou, J. Kigel, M. Kleyer, V. Lehsten, J. Leps, T. Meier, R. Pakeman, M. Papadimiriou, V. Papanastasis, H. Quested, F. Quétier, M. Robson, C. Roumet, G. Rusch, C. Skarpe, M. Sternberg, J. P. Theau, A. Thébault, D. Vile, and M. Zarovali. 2007. Assessing the effects of land-use change on plaits traits, communities and ecosystems functioning in grasslands: a standardized methodology and lessons from an application to 11 European sites. Annals of Botany 99:967-985.

Garnier, E., B. Shipley, C. Roumet, and G. Laurent. 2001. A standardized protocol for the determination of specific leaf area and leaf dry matter content. Functional Ecology 15:688-695.

GitaY, H., AND I. R. Noble. 1997. What are functional types and how should we seek them? In: T. M. Smith, H. H. Shugart, and F. I. Woodward [EDS.]. Plant functional types. Their relevance to ecosystem properties and global change. Cambridge, United Kingdom: Cambridge University Press. p. 3-19.

Hasenack, H., J. L. P. Cordeiro, and B. S. C. Costa. 2007. Cobertura vegetal atual do Rio Grande do Sul. Sustentabilidade produtiva no Bioma Pampa. In: M. Dall'Agnol, C. Nabinger, D. M. Sant'Anna, and R. J. Santos [EDs.]. II Simpósio de Forrageiras e Produção Animal. Porto Alegre, Brazil: Departamento de Forrageiras e Agrometeorologia-Universidade Federal Do Rio Grande do Sul. p. 15-22.

Knops, J., AND K. ReInHaRt. 2000. Specific leaf area along a nitrogen fertilisation gradient. American Midland Naturalist 144:265-272.

LANDSBERG, J. 2001. Response and effect-different reasons for classifying plant functional types. Proceedings of the VI International Rangeland Congress 2:911-915 p.

Landsberg, J., S. LAvorel, AND J. Stol. 1999. Grazing response among understorey plants in arid rangelands. Journal of Vegetation Science 10:683-696.

Lemaire, G., and F. Gastal. 1997. N uptake and distribution in plant canopies. In: $G$. Lemaire [ED.]. Diagnosis of the nitrogen status in crops. Berlin, Germany: Springer-Verlag. p. 3-43.

Lepš, J., F. de Bello, S. Lavorel, and S. Berman. 2006. Quantifying and interpreting functional diversity of natural communities: practical considerations matter. Preslia 78:481-501.

LOUAULt, F. 1999. Dynamics of dead and living plant material in grasslands under non-intensive use. Proceedings of the VI International Rangeland Congress, Townsville, Australia 1:274-275.
Louault, F., V. D. Pillar, J. Aufrère, E. Garnier, and J. F. Soussana. 2005. Plant traits and functional types in response to reduced disturbance in a semi-natural grassland. Journal of Vegetation Science 16:151-160.

Martins, C. E. N., AND F. L. F. Quadros. 2004. An electronic sheet to evaluate the dry matter availability ad the botanical composition of grasslands. In: Proceedings of the FAO-Grupo Campos Meeting, Salto, Uruguay. p. 229-231. (In Portuguese).

Matsuoka, M., N. A. Mello, J. C. Salton, and P. C. F. Carvalho. 2004. Biological attributes of a soil submitted to different grazing pressures. Proceedings of XXVI Reunião Brasileira de Fertilidade do Solo e Nutrição de Plantas, X Reunião Brasileira Sobre Micorrizas, VIII Simpósio Brasileiro de Microbiologia do Solo, V Reunião Brasileira de Biologia do Solo, Lages, Brazil. (In Portuguese).

Mello, N. A., J. C. Salton, M. Matsuoka, P. C. F. Carvalho, and J. A. Zanatta. 2004. Chemical attributes of a soil submitted to different grazing pressures. Proceedings of XXVI Reunião Brasileira de Fertilidade do Solo e Nutrição de Plantas, X Reunião Brasileira Sobre Micorrizas, VIII Simpósio Brasileiro de Microbiologia do Solo, V Reunião Brasileira de Biologia do Solo, Lages, Brazil. (In Portuguese).

Nabinger, C. 2002. Sustainable management of rangelands ecosystems. In: E. Lima Araújo, A. Nascimento Moura, E. V. Sá Barreto Sampaio, L. M. Souza Gestinari, and J. Melo Torres Carneiro [eds.]. Biodiversity, conservation and sustainable use of the Flora of Brazil. Recife, Brazil: Universidade Federal Rural de Pernambuco/Imprenta Universitária. p. 101-105. (In Portuguese).

Nabinger, C., A. Moraes, and G. E. Maraschin. 2000. Campos in Southern Brazil. In: G. Lemaire, J. Hogdson, A. Moraes, P. C. F. Carvalho, and C. Nabinger [EDs.]. Grassland ecophysiology and grazing ecology. Wallingford, CT: CABI. p. 355-376.

PILLAR, V. D. 2004. SYNCSA software for character-based community analysis. Version 2.2.4 and MULTIV software for multivariated analysis, randomization tests and bootstrap autoresampling, version 2.3.9. Porto Alegre, Brazil: Departamento de Ecologia, Universidade Federal Do Rio Grande do Sul.

Pillar, V., And E. E. Sosinski, JR. 2003. An improved method for searching plant functional types by numerical analysis. Journal of Vegetation Science 14:323-332.

Poorter, H., and M. Bergkotte. 1992. Chemical composition of 24 wild species differing in relative growth rate. Plant, Cell and Environment 15:221-229.

Poorter, H., C. Remkes, and H. Lambers. 1990. Carbon and nitrogen economy of 24 wild species differing in relative growth rate. Plant Physiology 94:621-627.

RYser, P. 1996. The importance of tissue density for growth and life span of leaves and roots: a comparison of five ecologically contrasting grasses. Functional Ecology 10:717-723.

Ryser, P., and H. Lambers. 1995. Root and leaf attributes accounting for the performance of fast- and slow-growing grasses at different nutrient supply. Plant and Soil 170:251-265.

Sinoquet, H., B. Moulia, F. Gastal, R. Bonhomme, and C. Varlet-Grancher. 1990. Modelling the radiative balance of the components of a well mixed canopy: application to a white clover-tall fescue mixture. Acta Oecologica 4:469-486.

Sosinski, E. E., JR., AND V. D. Pillar. 2004. Reponse of functional types of plants to the management of the native vegetation Pesquisa. Agropecuaria Brasileira 39:1-9. (In Portuguese).

Tothill, J. C., J. N. G. Hargreaves, and R. M. Jones. 1992. BotanAL-a comprehensive sampling and computing procedure for estimating pasture yield and composition. 1. Field sampling. Tropical Agronomy Technical Memorandum 78:1-24.

US Department of Agriculture Soll Survey Staff. 1999. Soil taxonomy-a basic system of soil classification for making and interpreting soil survey (2nd ed.). Washington, DC, USA: USDA. $871 \mathrm{p}$.

Vesk, P. A., M. R. Leishman, And M. Westoby. 2004. Simple traits do not predict grazing response in Australian dry shrublands and woodlands. Journal of Applied Ecology 41:22-31.

Watkinson, A. R., and S. J. Ormerod. 2001. Grasslands, grazing and biodiversity: editors' introduction. Journal of Applied Ecology 38:233-237.

Weiher, E., A. Van der Werf, K. Thompson, M. Roderick, E. Garnier, and 0. Eriksson. 1999. Challenging Theophrastus: a common core list of plant traits for functional ecology. Journal of Vegetation Science 10:609-620. 